\title{
GOLM1 Gene
}

National Cancer Institute

\section{Source}

National Cancer Institute. GOLM1 Gene. NCI Thesaurus. Code C71021.

This gene is involved in both the trafficking and posttranslational modification of proteins. 